\title{
Images of Dionysos from 430 BC onwards
}

\section{Dionysos on Stage}

The visual arts did not provide the only means through which in Classical Athens images of Dionysos were communicated to the public: the appearance of the god on the stage must have been equally effective-perhaps even more so. In order to produce the desired effect, Dionysos must have appeared in a way that was instantly recognizable and at least partly appealed to the audience's familiar mental picture. In short, his appearance must have been in accordance with the iconography we know. On the other hand we may presume that the most impressive stage appearances in their turn influenced the imagery; as will be shown in what follows, this was especially the case with the Dionysos of the Bakchai. Most of the plays that have come down to us are incomplete and for this reason it is often impossible to tell if and how Dionysos was presented. Only three examples from the 5 th century allow us to draw some conclusions concerning the outward appearance of the god. All three may be dated in the decades between 430 and 400 BC: Kratinos' Dionysalexandros, Frogs by Aristophanes, and Euripides' Bakchai. The enormous impact of the latter was still discernable in Hellenistic times. ${ }^{1}$

\section{Kratinos' Dionysalexandros}

Dionysalexandros, a comedy by Kratinos, was first performed in 430 or 429 BC. Apart from a few fragments of the original text, only a summary (hypothesis), composed around $200 \mathrm{AD}$, remains. ${ }^{2}$ It tells us of Dionysos impersonating Alexandros, otherwise known as the shepherd and Trojan prince Paris, the protagonist of the Judgment of Paris, which is actually acted out on the stage. Dionysos-Alexandros subsequently goes to Sparta to abduct the beautiful Helena. Back on the Ida, the two hide for fear of the invading Greeks. The real Paris appears and decides to turn the couple over to the Greeks. He takes pity on Helena, however, and makes her his wife; Dionysos is handed over, accompanied by wailing satyrs. The hypothesis explicitly mentions that the

1 The subject was first discussed in Isler-Kerényi 2011b. For a more complete overview of the imagery, see Isler-Kerényi 2012a.

2 Bakola 2010, especially 180-272; Imperio 2011, 303-310. Concerning Dionysos in Attic comedy, see Casolari 2003, especially 98-112 devoted to Dionysalexandros. 
play's intention was to draw a bead on Perikles, who had brought war to the Athenians.

What Dionysos looked like when in Kratinos' play he appeared as Paris may be deduced from the history of the imagery of the Judgment. In the 6th century the Trojan prince is presented as bearded; from the $5^{\text {th }}$ century onwards he is youthful. ${ }^{3}$ It is precisely around $430 \mathrm{BC}$ that vase imagery shows the turnabout from Greek shepherd to Oriental with multi-colored leggings. ${ }^{4}$ It is possible that this change of costume can be attributed to a flash of wit of Kratinos'. Just the idea to cast the god in the role of the young lover could have been an ironic comment on the new Dionysos of the Parthenon, whose youthful beauty was, as we have seen, particularly highlighted both in the east pediment and in the east frieze. If, as Kratinos suggests, it was Dionysos who had caused the Trojan War, the contrast with the relaxed reclining god must have been all the more striking. In vase painting the oriental garb of Paris stresses the fact that the war had turned into a confrontation between Greece and Asia; a Dionysos (who in reality was strongly associated with the polis of Athens, as we have seen) decked out in oriental leggings must have produced a paradoxical and shocking effect comparable to the ridiculous Dionysos presented by Aristophanes. This probably made the criticism directed at Perikles even more acrimonious.

\section{Aristophanes' Frogs}

Aristophanes' comedy is named after its chorus of frogs. It was probably written after Euripides' Bakchai and had its premiere in Athens in January of the year 405 BC. $^{5}$ Its comic mood is established right at the beginning when Dionysos enters with his servant Xanthias, who is riding a donkey. This would have immediately reminded the audience of the motif of the return of Hephaistos, so often depicted at the time on vases and in monumental art. ${ }^{6}$ The announcement that the two were not on their way to the Olympus but to Hades, must have led to peals of laughter. ${ }^{7}$ Dionysos was on his way there to bring back Euripides who had just died. From the words of Herakles and Charon, with whom he meets, we can conclude that Dionysos is presented as young and rather chubby. ${ }^{8}$ During the first half of the play the audience was regaled with the pair's adventures in the underworld. Dionysos' frequent

3 LIMC VII.1, 186-188 (A. Kossatz-Deissmann concerning Paridis iudicium).

4 Lid of a pyxis, Copenhagen 731: BA 7928; LIMC viI Paridis Iudicum 40.

5 Lada-Richards 1999, 17.

6 Lada-Richards 1999, 156; for the painting in the temple of Dionysos see Natale 2008, $107 \mathrm{f}$.

7 Ar. $R a .69$.

8 Ar. Ra. 60 (adelphidion), and 200 (gastron). 
disguises as Herakles or Xanthias (and the fact that he was just as frequently unmasked) must have been genuinely funny; we can see him continually putting on the lion skin over his saffron yellow chiton - and taking it off again. Incidentally, it is probable that the traveler as well as the slave wore a short chiton instead of a long one. ${ }^{9}$ The many disguises and changes of costume were very likely meant as a parody of the theater itself. ${ }^{10}$ In the second part, in which Dionysos features as adjudicator between Euripides and Aischylos, he may have appeared as a dignified figure in a long robe - as referees are usually depicted in vase painting. ${ }^{11}$ At the end of the comedy it is not Euripides who, for the greater good of the polis, is led out of Hades by Dionysos, but Aischylos who represents the polis' good old days. Here Dionysos assumed his familiar role of mediator and liberator-as he did when he brought back Hephaistos. Everyone in the audience knew that he had not only accompanied his unfortunate brother back to the Olympus, but also brought his own mother from Hades to heaven and, in so doing, had granted eternal life to her who had died so young. Thus, from the moment he came onto the stage and even before he had uttered a single word, Dionysos delivered a message of hope and reconciliation to the Athenians just before the disastrous end of the Peloponnesian War. ${ }^{12}$

\section{Euripides' Bakchai}

The subject of Euripides' Bakchai is the horrible punishment of Pentheus, king of Thebes. The sudden entry of Dionysos at the beginning of the play can only have provided the desired theatrical effect when the god was immediately recognized by the audience. Even when Euripides would have added new elements to Dionysos' outward appearance, it must have answered to the visual expectations of the audience and fitted into the iconographical landscape of his time. On the other hand, because of the tremendous success of the play in the centuries that followed, it is more than likely that this particular Dionysos had a Nachleben in the imagery. ${ }^{13}$ What does the text tell us about the way he looked? From the words of Pentheus we can deduce that the god had long blonde locks and was young and effeminate. ${ }^{14}$ An additional element is the fact that he is said to have just arrived from Asia, that is: from afar.

\footnotetext{
9 Compare the slightly older representations of Herakles: LIMC IV, Herakles 1477 and 1562.

10 Tasinato $2003,13-15$.

11 Compare for instance Berti-Restani 1988, 72, fig. 17, and 74, fig. 19.

12 Similarly Lada-Richards 1999, 326-329.

13 For the successes of the play, see Seaford $1996,5^{2} \mathrm{f}$.

14 E. $B a \cdot 235^{-236}$ und $455^{-459}$.
} 
The iconography of Pentheus' death in vase painting is not very helpful. ${ }^{15}$ It starts at the end of the 6th century, with very gruesome images, and continues until about 480 BC. Dionysos only appears on the cup by Douris in Fort Worth (Tx); bearded and wearing a long robe, he sits dignifiedly as the hectic, bloodthirsty events take place around him. Only forty years later the subject comes up again on the lekanis lid discussed earlier, and subsequently on the badly preserved hydria by the Meidias Painter. ${ }^{16}$ Dionysos appears on both, although it is possible that he is supposed to be invisible; he is young, naked, and very much like the punishing Apollo. Nevertheless, we can hardly presume he appeared naked on the stage. We do not know if he already appeared as a young man in the Pentheus tragedies by Thespis, Aischylos and Xenokles, which preceded Euripides' play. ${ }^{17}$ In view of what we know of his iconography, this does not seem very probable.

This is everything vase painting has to offer. Of the sculptural types that may have existed at the time of Euripides, neither the bearded nor the naked god seems eligible. Likewise improbable, because he wears a long garment unsuitable for a traveler, is the type of the young, long-haired kithadoros in the west pediment of the temple of Apollo in Delphi. ${ }^{18}$ On the other hand, the Bakchai may have inspired a Dionysos type that, for stylistic reasons, is dated in the early 4th century and is known from several copies and versions in relief. ${ }^{19} \mathrm{He}$ has long, flowing locks, and wears a short robe and boots, which would be suitable for both the traveler and the actor. As has been mentioned above, the panther skin refers to Asia, from where the god just came. The femininity of his appearance is not confined to the face framed by the long locks. None of the other male children of Zeus would wear a short chiton with an animal skin over it; only Artemis does. In fact, a votive relief was found not far from the so-called Chapel of Dionysos on Delos which shows a Dionysos who could have been Artemis, but for the cluster of grapes and the panther. ${ }^{20} \mathrm{~A}$ mold for a goblet from Hellenistic times makes it clear that this type was known as

15 March 1989; LIMC VII.1, 315-317 (J. Bažant/G. Berger-Doer); Weaver 2009.

16 For the cup: see above Chapter 3 , note 83 fig. 31. For the lekanis lid: see above Chapter 7 , note 42 , and 8 , note 66 . For the hydria: Chapter 8 , note 64 .

17 Aélion 1983, 251-254.

18 Croissant 2003, 85-87, pls. 34-41.

19 LIMC III, Dionysos 128; Cain 1997, 30-34.

20 Isler-Kerényi 2012a, fig. 7. In addition Marcadé 1996, 182 f.: "Et pourtant, de manière extrèmement singulière, c'est à Artémis que font penser le vêtement, la coiffure et même les bottines." (Ph. Jockey). 


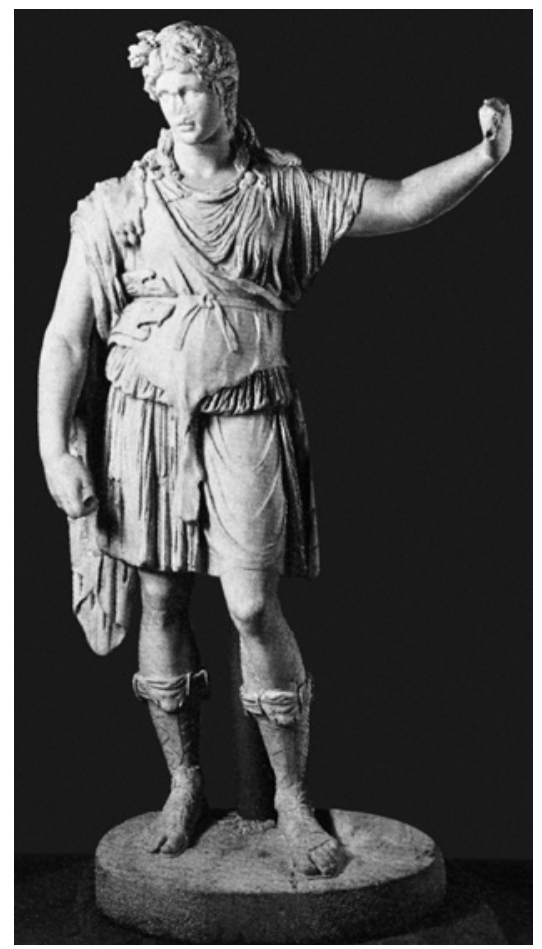

FIGURE 110 Dionysos in Euripides' Bakchai (photomontage C. Isler-Kerényi).

Thriambos. ${ }^{21}$ And, after all, this suits the memory of the triumphant Dionysos of the Bakchai (Figure 110).

This Dionysos type is not only preserved in an impressive Hellenistic bronze statuette and copies from the Imperial period, but also in some 4 th-century votive reliefs from Greek sanctuaries, as well as sporadic vase images. ${ }^{22}$ The neck of an Apulian volute krater provides an explicit reference to Euripides' tragedy, although, unfortunately, the only available photograph presents the image in a much disfigured form. ${ }^{23}$ We see Dionysos, who, on the extreme left, watches the furious maenads killing Pentheus, while Nike flies towards

\footnotetext{
21 Cain 1997, 34.

22 For the bronze statuette, see Karusu 1975. For the copies: LIMC III, Dionysos 128 a-c. For the votive reliefs: Cain 1997, 30 and pl. 3. For an example of a vase image, see the lid of an Attic lekanis found at the south foot of the Acropolis, Athens Acropolis Museum 1956 NAK 232, with Dionysos amidst women and maenads (I am indebted to Victoria Sabetai for this personal communication).

23 LIMC VII, Pentheus 16.
} 


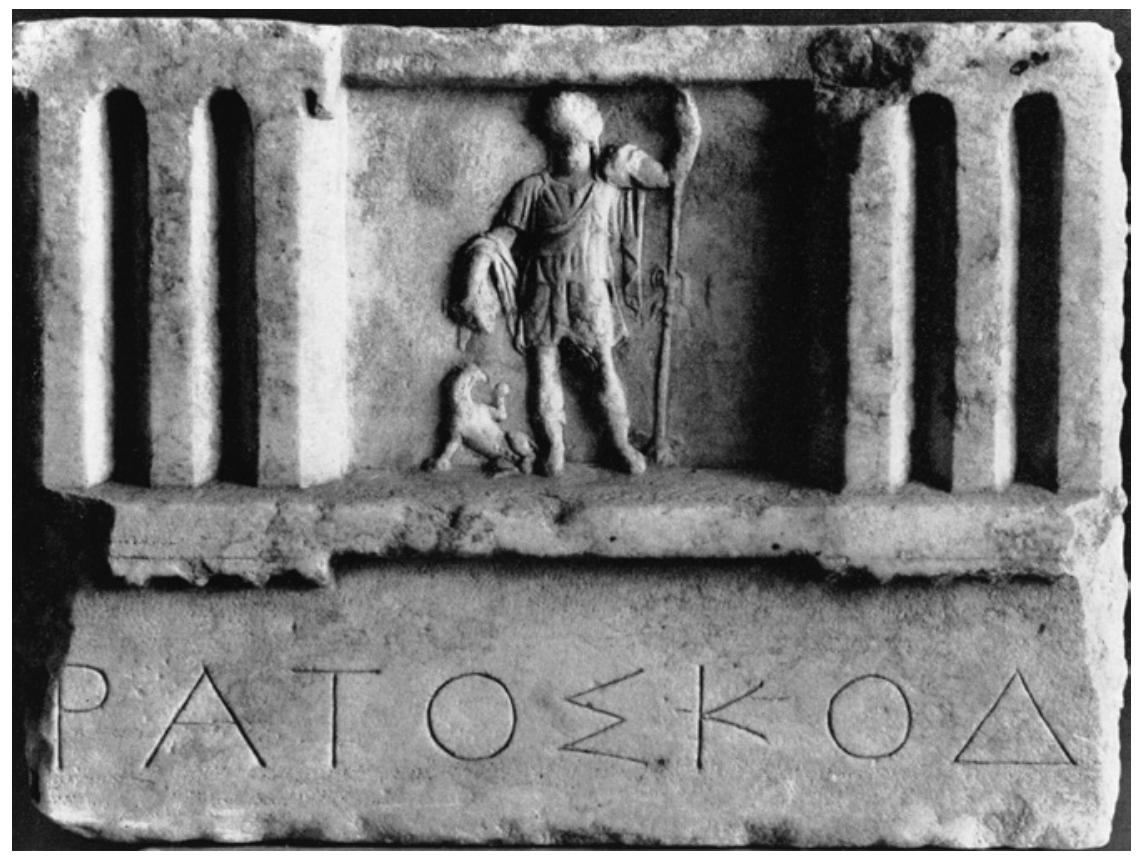

FIGURE 111 Theater of Thasos, metope (всн 84, 1960, 301, fig. 1).

him with a wreath; apparently here, too, he is seen as triumphant. The god is young and wears a short chiton and boots; whether he also wore an animal skin is now impossible to make out. A relationship between this Dionysos type and the world of the theater may also be discerned in an, unfortunately badly preserved, votive relief found near the theater of Dionysos in Athens. ${ }^{24}$ Other examples are a relief (refurbished in the 2nd century AD) from the metopes of the scene house of the theater of Thasos, (Figure 111) and one of the Imperial-period reliefs. ${ }^{25}$ These latter decorate the stage front of the socalled Phaidrosbema of the theater of Dionysos in Athens and show various scenes from Dionysiac mythology. Our type is shown in the scene depicting the presentation of the vine to the Attic heros Ikarios-likewise a tragic tale. ${ }^{26}$

If indeed the triumphant Dionysos of the Bakchai lives on in this type, it is not hard to imagine what the audience's visual associations must have been. First of all, there is the association with Artemis, the ruler of the wilderness and of untamed women - the world into which Dionysos the punisher leads

\footnotetext{
24 LIMC III, Dionysos 853.

25 Salviat 196o, 314 f.; Daux 1968, 54.

26 LIMC III, Erigone I 1.
} 
the maenads, cut loose from the well-ordered community. In addition, the short chiton with the animal skin over it would have reminded the Athenians of Dionysos Gigantomachos, known from the second metope on the east side of the Parthenon and from somewhat older vase imagery. Incidentally, this way of depicting Dionysos as a combatant remains canonical after Euripides, as is borne out by mirror reliefs and vase paintings of the 4 th century, ${ }^{27}$ and, eventually, by the Gigantomachy and Telephos friezes of the Pergamon altar. ${ }^{28}$

If we assume that Euripides really gave his Dionysos the appearance of the triumphant Gigantomachos, what sense would this have made?29 While Pentheus was under the impression that he was dealing with an Asiatic member of Dionysos' retinue, the audience immediately realized that this was the god himself: Dionysos who, with the other gods, had fought for the order of Zeus and had been victorious. The terrible punishment of the blinded Pentheus cannot have been a total surprise: ultimately, it was all for the good of the polis. ${ }^{30}$

\section{Dionysos in 4th-Century Sculpture}

We can be sure that at the end of the $5^{\text {th }}$ century at least three very distinct sculptural Dionysos types could be discerned: the relaxed, naked young god of the east pediment of the Parthenon; the young triumphant god of the Bakchai; and the gold and ivory cult statue of the temple at the sanctuary near the theater, created by Alkamenes, a close collaborator of Phidias. ${ }^{31}$ The latter, as is evident from coins from Imperial times, reverted to a traditional type: that of the dignified, bearded enthroned Dionysos, the one who resembled the Zeus of Olympia. ${ }^{32}$ Although the Parthenon type was extremely popular in vase painting and small statuary, it had, as far as we know, no follow-up in monumental sculpture. It has been argued above that this may be related to the fact that the vision of peace that was at the basis of the sculptural program of the Parthenon had been rendered obsolete by the outbreak of the Peloponnesian war. On the other hand, the idea of Dionysos and his promise of Bacchic bliss

\footnotetext{
27 For instance LIMC III, Dionysos 633 and 641.

28 Isler-Kerényi 2010b.

29 It may not be a coincidence that in E. Ba. 537-544 the chorus associates Pentheus with the giants (I am indebted to Richard Seaford for pointing this out to me).

3o March 1989, 65; Seaford 2006, 49.

31 What follows largely corresponds with Isler-Kerényi 2011 .

$32 \quad$ LIMC III.1, 446 Dionysos 214.
} 
gained pregnancy in the current dangerous situation and it was given a significant place in vase imagery, which also suited the function of funerary gift. ${ }^{33}$

There must have been other sculptural representations of Dionysos-as Pausanias tells us: the god had many sanctuaries in Greece. ${ }^{34}$ Some cult statues were old, or archaistic, xoana and sphyrelata. ${ }^{35}$ This is illustrated by two Apulian vase images, where statues of this kind are shown next to the real, young god. ${ }^{36}$ Others, of which we know nothing, were newly created in the 4 th century by artists active at the time.

In any case, as we have seen, multiformity seems to have been a characteristic of Dionysos ever since the final years of the 5 th century. ${ }^{37}$ This multiformity even found ritual expression: a procession with two Dionysos statues (one the Bakcheios, the other the Lysios) regularly took place in Sikyon. ${ }^{38}$ Greek coins, too, show Dionysos in a multitude of guises, although in many cases it is uncertain when they were formed. The standing, bearded god in the long chiton or the himation that leaves the chest bare was probably a type of the Classical period. ${ }^{39}$ The same holds true for the youthful, standing nude figure. ${ }^{40} \mathrm{On}$ coins from Thessaly, Crete and Athens, Dionysos appears bearded and seated like Alkamenes' cult statue; the earliest of these coins may be dated to around 470 BC. ${ }^{41} \mathrm{He}$ is depicted youthful and seated on Greek coins from the 4th century onwards, as well as on wall paintings from the Imperial period. ${ }^{42}$ Finally, the infant Dionysos may be found on coins from Thrace and Asia Minor of the $5^{\text {th }}$ and 4 th centuries. ${ }^{43}$ It is, however, impossible to know whether these figures reflect cult statues or local Dionysiac myths.

The so-called Dionysos Sardanapalos probably appeared in the 4th century (Figure 112). This Dionsyos, in a long, rich robe, bearded and with an elaborate long hairstyle, may have been created for the theater of Dionysos in the circle of Praxiteles. ${ }^{44}$ A choragic monument of about 340 BC presents a very similar

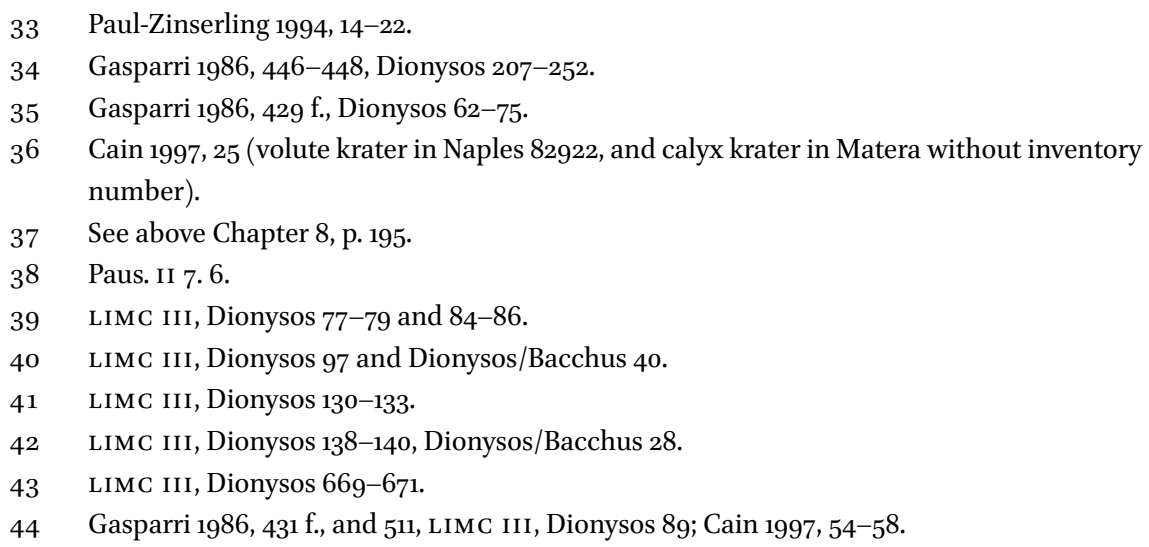




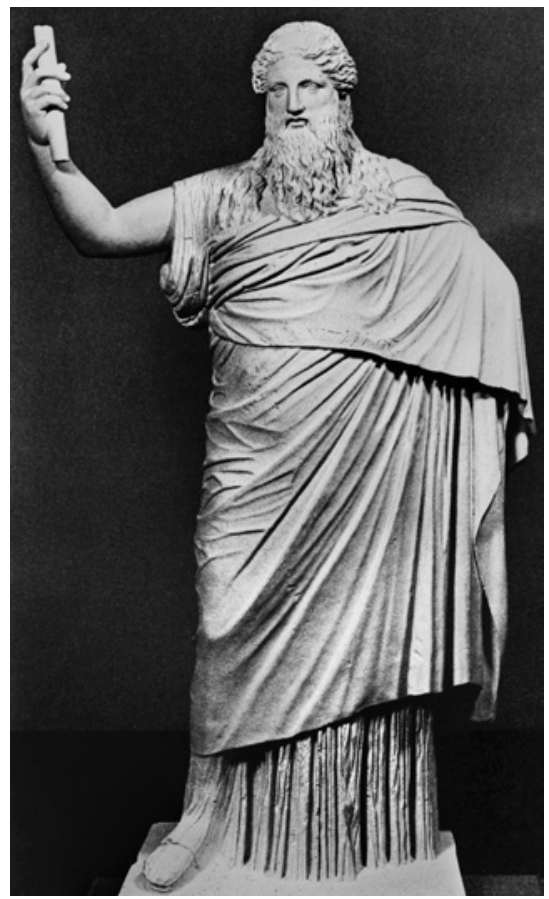

FIgURE 112 Dionysos Sardanapalos, Rome, Musei Vaticani, Sala della Biga 2363 (Cain 1997, pl. 16).

figure..$^{45}$ Dionysos Kitharodos of the west pediment of the temple of Apollo in Delphi, mentioned above, is likewise wearing a long robe, but he is a youthful standing figure surrounded by the members of his thiasos (Figure 113). ${ }^{46}$ The pediment was made by artists from Athens between 360 and $330 .{ }^{47}$ As we have seen, after 430 this kind of typological similarity to Apollo can also be found in vase painting. ${ }^{48}$ It may be explained from the fact that the two divine brothers

\footnotetext{
45 LIMC III, Dionysos 88.

46 See above note 18.

47 LIMC III, Dionysos 489 (body) and 205 (head): Croissant 2003, $30 \mathrm{f}$. and 85 has convincingly shown that the two belong together. The identification of this figure as Apollo in LIMC II, 201 concerning Apollo 101 (Lambrinudakis) has been refuted by the archeological circumstances and is out of date. A colossal head of Dionysos, datable to around 340 BC or somewhat later, from the sanctuary of Dionysos on Thasos, is very comparable because of its effeminate appearance and its erotic aura, see LIMC III, Dionysos 206; Holtzmann 2010, 268 f., no. 77 .

48 See above Chapter 7, p. 171 , note 42.
} 


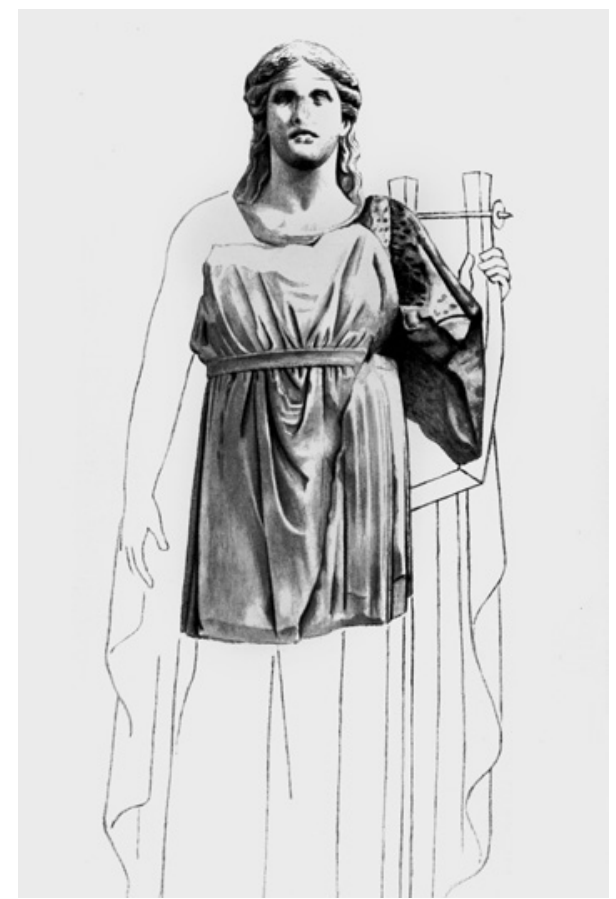

FIGURE 113 Dionysos Kitharodos, west pediment of the temple of Apollo, Delphi, Museum 2380 (Croissant 2003, pl. 34, drawing K. Iliakis).

had complementary functions in the Olympic family ruled by Zeus and, consequently, in the human world.

The various shapes and forms of Dionysos we have looked at so far, bear out his multiformity in monumental art and in public space. They completely answer to modern expectations about divine grandeur and credibility in cult statuary. The figure of the young, almost or completely naked god in a relaxed attitude, mainly preserved in copies from the Roman Imperial Period, is, however, different and more problematic. ${ }^{49}$ The origin of this frequently modified type lies in the 4th century and is stylistically close to Praxiteles who, according to the sources, created more than one statue of Dionyos. ${ }^{50}$ In the years that followed the prototype underwent several, be it superficial, changes (Figure 114). ${ }^{51}$ The young and erotic Dionysos whose himation has slipped to his thighs so that his

49 Concerning this issue, see Cain 1997, 12-14 and 77-79.

50 LIMC III, Dionysos 120. For statues by Praxiteles mentioned in literary sources: LIMC III, Dionysos 215-217.

$5^{1} \quad$ LIMC III, Dionysos 121-124; Cain 1997, 78. 


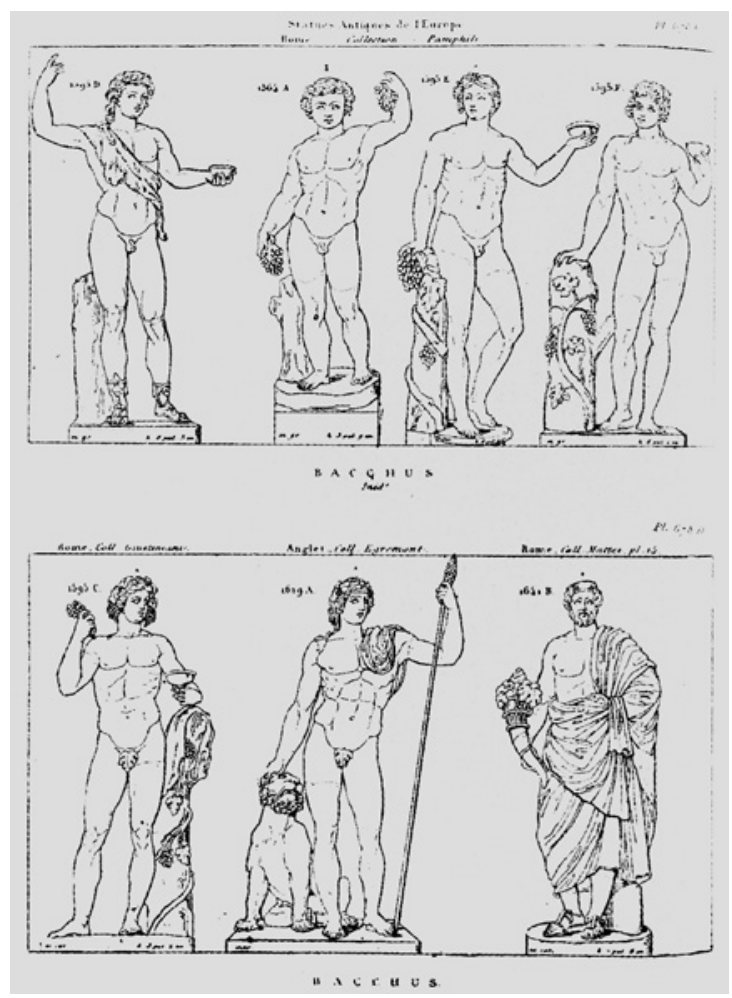

FIGURE 114 Various statues of the youthful Dionysos, Roman Imperial period (Cain 1997, 78 above left).

genitals are revealed, must be of comparable origin. ${ }^{52}$ The motif of the effeminate youth expresses itself even more clearly in small statuary and is subsequently applied to larger sizes; here we see a Dionysos who is no longer able to stand on his own two feet, but is has to be supported by a companion. ${ }^{53}$

As we have seen, the youthful Dionysos was officially introduced with the Parthenon sculptures. Phidias gave him the body of an athletic adult. The Praxiteles type, however, is an ephebe who increasingly resembles Eros and, like Eros, takes on an effeminate form. A possible explanation for this androgynous Eros may be that Eros, as the god of all commencements, unites several potential forms of existence: male and female; human, animal and vegetal. ${ }^{54}$ As Bakchos, Dionysos, too, is a god of initiation, and as such of new beginnings.

$5^{2} \quad$ LIMC III, Dionysos 126 and 127, also Dionysos/Bacchus 181 and 186.

53 Pochmarski 1990.

54 Isler-Kerényi 2004b, 247. 
Dionysos' feminine aspect increasingly goes hand in hand with a passive, relaxed attitude; all of this was the complete opposite of what was expected from a citizen. Nevertheless, the god seems to have remained a significant figure. By revealing his genitals he presents himself as the seducer, not only of Ariadne, but also of the human beings who met him in the sanctuaries of Greece and the gardens of Rome. ${ }^{55}$ The meaning of this aspect of Dionyos will become clearer when we compare the sculptural type with its counterpart in vase painting, in other words: when matters are viewed in context.

\section{A Look at Vase Painting}

For the vase painters active in the decades between the Dinos and Pronomos Painters and the so-called Kerch style, Dionysos was clearly the most important god. ${ }^{56}$ This is not only evident from the output of the Meleager Painter and his workshop, which mainly produced kraters, but also from the workshop of the Jena Painter, the leading producer of cups. ${ }^{57}$ According to Verena PaulZinserling the great importance of Dionysos and his retinue in vase imagery reflects the significance of Bacchic ceremonies in the lives of the buyers of the ceramics. ${ }^{58}$ Because vase painting is allusive instead of descriptive, this is hard to prove. Nevertheless, as will be clear from what we have seen and from what follows, the development of Dionysiac iconography certainly supports this proposition.

As far as choice of subject is concerned, we first of all notice that in the first decades of the 4th century traditional mythological themes (including the return of Hephaistos with its special significance for the polis, which regularly occurred until around $400 \mathrm{BC}$ ) are as good as absent-with the exception of the Gigantomachy. ${ }^{59}$ Future scholarship should make a special study of the marked differences between the image repertoire of the first quarter of the century and that of the second quarter, and look at the various phenom-

55 Fragmentary Apulian calyx krater, Taranto 52.230: Isler-Kerényi 2011a, 81, fig. 10; Tiverios 2011, 163 and 169, fig. 11 .

$5^{6}$ Boardman 1989, 10 (dating of the Kerch style in the second and third quarter of the century) and 190-193 (Kerch style ceramics); for an extensive study of the dating of 4 thcentury Athenian ceramics, see Langner 2013.

57 Meleager Painter: Kathariou 2002, 27-37; Jena Painter: Paul-Zinserling 1994.

$5^{8}$ Paul-Zinserling 1994 passim, especially 32 and 70. Kathariou 2002, 35 remains sceptical about this.

59 Natale 2008, 99-106. 
ena against the background of the political and cultural situation in Athens at the time. Of the types we found in sculpture, the bearded Dionysos does not appear in vase painting and neither do the fully dressed types such as the so-called Dionysos Sardanapalos and the Kitharodos type from Delphi. After the Kadmos Painter, the regal seated Dionysos like the one by Alkamenes no longer occurs. ${ }^{60}$ The victorious Dionysos of the very few Gigantomachy scenes wears only a himation that leaves his chest bare or a long himation, and in this way differs from Dionysos Gigantomachos in sculpture. ${ }^{61}$ In any case, a dressed Dionysos is much rarer than a completely or almost naked one. Images of a standing Dionysos are not very numerous and rarely correspond to those in large-size sculpture. ${ }^{62}$ The walking god may be supported by Ariadne, Herakles, a satyr or even Eros. ${ }^{63}$ When, under the influence of music, wine, or love (or all of these together), he appears in a euphoric mood, this does not seem to refer to a specific myth, but to a state that is considered characteristic of him. Most often we find Dionysos as he was depicted by the Dinos or the Kadmos Painter: naked, in a relaxed seated pose, receiving gifts from the members of his retinue, or being tenderly caressed by Ariadne (Figure 115). ${ }^{64}$

A standing naked Dionysos similar to the Praxiteles type from sculpture may be found, for instance, on a calyx krater of the so-called LC Group from the middle of the century. ${ }^{65}$ This group of vases of mediocre quality was probably not manufactured in Athens itself, but in a Boeotian workshop. ${ }^{66}$ The group, however, shows an image repertoire and iconography that is almost indistinguishable from those used in Attica as a result of the fact that in the course of the 4th century manufacture and form throughout Greece, and even in Greek Southern Italy, had become increasingly similar under the influence of the magnificent Athenian creations of the Parthenon epoch. ${ }^{67}$

\footnotetext{
6o LIMC III, Dionysos 598 .

61 Paul-Zinserling 1994, 35-37; LIMC, Dionysos 660 and possibly also 630; LIMC, III Dionysos 631 (= LIMC IV, Gigantes 389), which seems Attic rather than Apulian, see Kästner 2008b, 188 , cat. 38 .

62 For instance LIMC III, Dionysos 315 and 316.

63 Some examples: LIMC III, Dionysos 720 (= Kathariou 2002, 404, fig. 39 B), 583 (bearded here), 584, 834; Kathariou 2002, 391, fig. 14 Г.

64 Two examples: bell krater Budapest 50.568: ARV 1439.1; BA 218088, and pelike St. Petersburg St. 1793: Furtwängler/Reichhold 1904-32 text volume II, 47. Concerning the motif: Kathariou 2002, 197, and pl. 414, fig. 57 A; LIMC III, Dionysos 731.

65 Athens 1376: ARV 1458.34; BA 218307 (no image); Schefold 1934, 25, no. 205 pl. 46. From Boeotia.

66 Schöne-Denkinger 2009, 89 f.; Sabetai 2011, 157, note 83.

67 Borbein 1995, $436 \mathrm{f}$.
} 


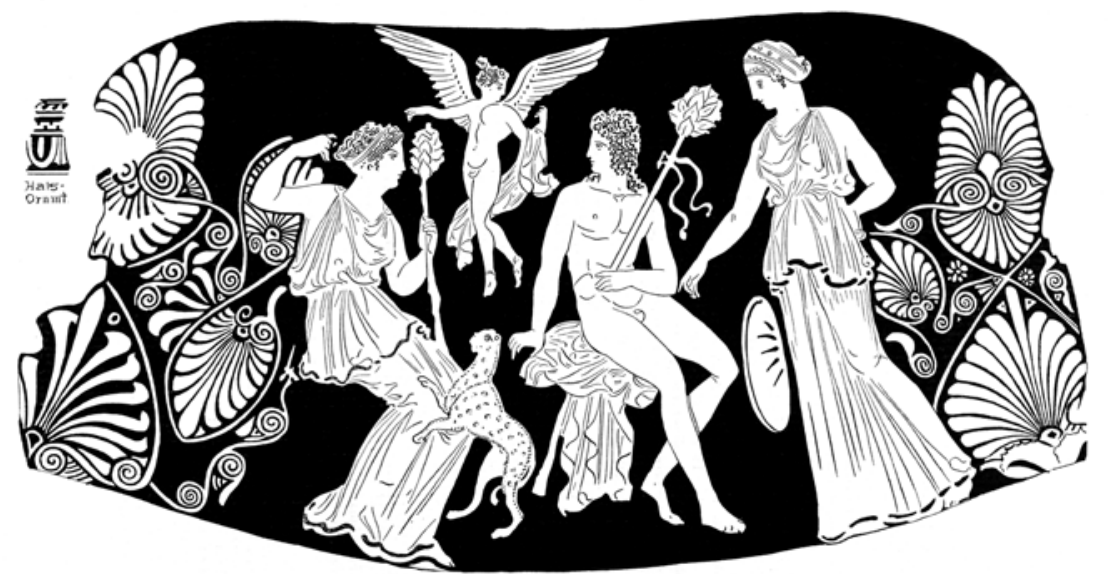

FIgure 115 Pelike, St. Petersburg, State Hermitage Museum St. 1793 (FR, Text II, 47).

The composition of the image on one side of the vase is very clear (Figure 116). In the middle on the left we see a standing young Dionysos wearing a wreath. His himation, held by his right elbow, leaves his whole body bare. Behind his left shoulder we can discern a thyrsos. The god is gazing at a woman who sits on his right; the uncovered parts of her body are highlighted in white. On the floor between the two is an altar. Above it, on an elevation in the landscape that is not indicated, stands Eros. He turns towards the woman, his wings spread. He has taken a necklace or another piece of jewelry, no longer visible, from a flat box in his left hand. He wears his hair in a chignon on the top of his head-a feminine style. His body also has the conspicuous white color. To the left of Dionysos, a satyr wearing a panther skin over his left arm, looks back towards the main scene. Another woman stands to the right of the seated one. Her raised hairstyle perhaps indicates she is elderly. Between her and Eros we see Pan approaching with a ribbon in his right hand. It is only in the 4 th century that the figure of Pan appears in the Dionysiac repertoire of the vase painters. ${ }^{68}$ As on the Roman sarcophagi of a much later period, he may represent the wild, unpredictable world beyond what can be experienced by mortals - a world only known in death. ${ }^{69}$ The image apparently means to show an epiphany of Dionysos which precedes the erotic encounter. Beazley is wondering whether the seated woman could indeed be identified as Ariadne; Metzger interprets

68 Paul-Zinserling 1994, 43.

69 Isler-Kerényi 2012b, 73 and 75. 

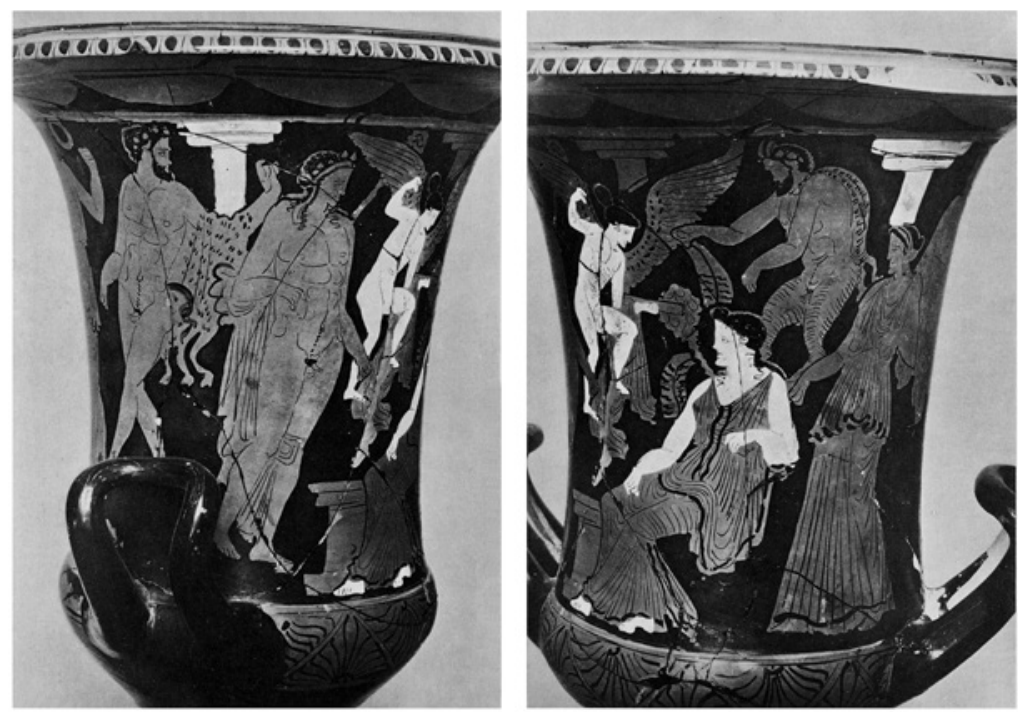

FIGURE 116

Calyx krater, Athens, National Museum 1376, two views of side A (Schefold 1934, pl. 46, no. 205).

the scene as "hiérogamie proprement dite."70 At the top of the image, partly highlighted in white, are the upper parts of three columns with capitals and architrave. Perhaps this refers to a temple front: together with the altar it would indicate that this encounter takes place in sacred space.

On the reverse the young, naked Dionysos presents himself in a way we know from countless other examples: reclining in the familiar pose of the east pediment of the Parthenon, in the company of Eros, a satyr, and a Dionysiac woman..$^{71}$

The idea of blissful peace, communicated by the Dionysos of the Parthenon's east pediment, here finds expression at a personal level in the unmistakable Bacchic atmosphere. It cannot be a coincidence that Hermes is often present in scenes of this kind - the god who is responsible for all transitions. ${ }^{72}$ His presence indicates the vessel was meant to be used as a grave gift. The meaning of the Dionysiac encounter on vases like the one just discussed, is evident: it promises erotic bliss. Or better perhaps - given the idea that vase paintings should be read in a metaphorical rather than a realistic sense: it promises a

\footnotetext{
$70 \quad$ Metzger 1951, 117, no. 16. Compare in addition the oinochoe LIMC III, Dionysos 731, where the erotic intent of the meeting is evident.

71 Compare for instance Schefold 1934, pls. 41 a-b, 45, and 47.

$72 \quad$ ARV 1457 f., 19.21.29.
} 
total state of felicity, like the one experienced in love. Approaching a statue of the naked ephebe Dionysos in a Greek sanctuary or a Roman garden was tantamount to having the prospect of perfect happiness.

There were other formulae with which to refer to acquired or prospective Bacchic bliss, for instance the ones we already met in the work of the Dinos Painter and the Kadmos Painter: Dionysos as a symposiast, alone, with Hephaistos or with Herakles. ${ }^{73}$ The idea is expressed in a more dynamic way when Dionysos, Ariadne close at his side, moves energetically towards the right, as he was depicted by the Pronomos Painter. Most of the time, however, it is not the god, but his companion who takes the lead. ${ }^{74} \mathrm{~A}$ similar role for women in a Bacchic context is not new and also found elsewhere. ${ }^{75}$ The numerous depictions of the seated couple could be considered a quiet version of the same formula. ${ }^{76}$ Eros bringing a bunch of grapes—whose "death" results in wine-clearly alludes to the Bacchic experience.

The examples presented here of the standing, young Dionysos turning towards Ariadne or a woman identifying with her, of the seated or reclining god, or of the euphorically advancing couple, were meant for the individual viewer and for private use. In addition, Attic vases have motifs that may have been derived from monumental, public art. Apart from the Gigantomachy already mentioned, the arrival of Dionysos riding a wild animal or enthusiastically driving a chariot drawn by animals also belongs to this category.

A fine example of the latter may be found on a calyx krater, datable to about 350 BC or shortly afterwards (Figure 117) ${ }^{77}$ It belongs to a manufacture that is known as Group $\mathrm{G}$ because of its many depictions of griffins. A relatively large number of these vases were found in the Black Sea area, but Kyrenaika (North Africa) and Spina are also well represented. Others were found in Olynthos (Macedonia) and in Athens. The usual vase type of this group is the pelike, followed at some distance by the bell krater. Only two calyx kraters made by Group $\mathrm{G}$ have so far been found. In our example, both the potter's work and the decorated parts indicate that it was an exceptionally ambitious piece for its time. In the photographs that have been published, the krater subsequently filed by Beazley, looks like a weaker piece. ${ }^{78}$ It also shows on one side two

\footnotetext{
73 Metzger 1951, 125-129; LIMC III, Dionysos 369, 559, 56o.

74 Compare Metzger 1951, 115. "Enlèvement d'Ariane" is therefore not the right expression.

75 Compare Jaccottet 2003, 88-94; Isler-Kerényi 2007, 154; Gasparri 1986, $483 \mathrm{f}$.

76 Metzger 1951, 118-120; LIMC III, Dionysos 738-740, 743, 748-750. For an example with a standing Ariadne: LIMC III, Dionysos 731-734.

77 Zurich, Archäologische Sammlung der Universität 3926: Addenda 380 (1470.164); вA 230374; Isler-Kerényi 1982 and 1983.

78 Whereabouts unknown: ARV 1470.165; BA 230375.
} 


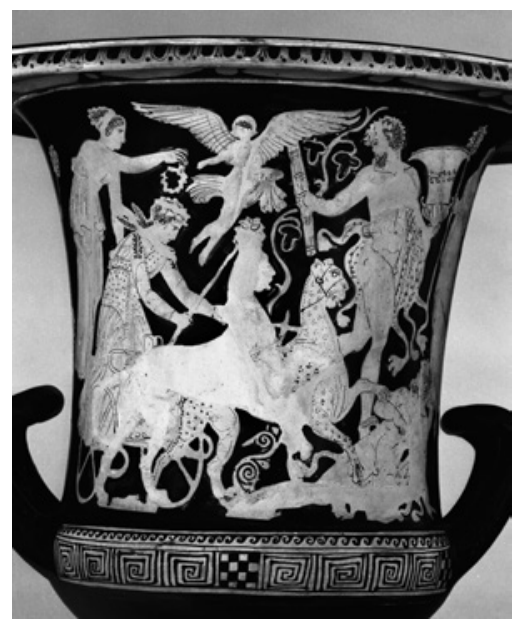

$a$

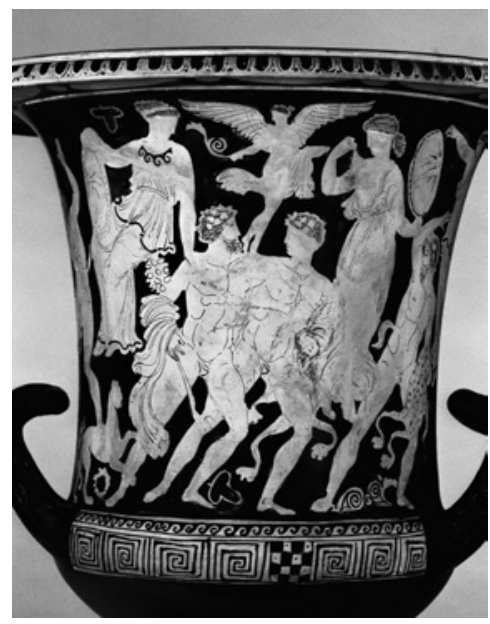

$b$

FI U URE 117 Calyx krater, Zürich, Archäologische Sammlung der Universität 3926 (photographs Archäologisches Institut der Universität Zürich, Silvia Hertig). a. side A: arrival of Dionysos.

b. side B: pair of Dionysiac men.

vigorously striding men, while the other has Dionysos reclining on the symposium couch.

As far as style and quality are concerned our calyx kraters most resemble bell kraters of the so-called Falaieff type, whose four fields of images, apart from griffins fighting amazons, all show the youthful Dionysos. ${ }^{79}$ In two instances he is reclining in a manner recalling the east pediment of the Parthenon as he watches a dancing maenad with a tympanon in her hand. The head of Dionysos (the delineation of his locks, his ivy wreath, his profile) on the krater in the Louvre so much resembles that on our krater, that it must have been created by the same hand. The clusters of grapes filling the space above the figures are, at any rate, almost identical. But because not much is known about this vase either, we can only conclude that the Bacchic Dionysos and his world apparently belonged to the more up-market segment of this manufacture.

The main side of our krater shows the young god wearing an animal skin over a long, flying chiton. He stands in a chariot drawn by two large panthers. In front of him a satyr has fallen to the ground in fear. In the upper part of the image another satyr precedes the god, half dancing, a torch in his right hand and a large wreathed calyx krater in his left. Eros spreads his wings as he hovers

79 Louvre G 530: Addenda 380 (1469.161); вA 230371; Louvre G 529: Addenda 380 (1469.162); BA 230372; Stockholm D 19310: Addenda 380 (1470.163); вA 230373 (no image). 
above the team of panthers. A woman with a vine leaf or a bunch of grapes is leaning over from the back. On the right edge of the image, a second maenad with thyrsos and tympanon is ecstatically turning around her own axis. Making a gesture of surprise, a third satyr looks on above the handle. Between the panthers, a vine that may have just sprouted from the earth fills up the space with its grapes. The panthers are shown in three quarter view and seem to detach themselves from the vase on order to move towards the viewer. It is clear that the latter should be duly impressed by the wondrous arrival of the god.

On the reverse two men wearing ivy wreaths are striding towards the right. The younger of the pair has thrown a lion skin over his left arm; the elder is carrying a thyrsos. It is probable that they are Herakles and Hephaistos. A cluster of grapes is on the ground between them. A satyr making an inviting gesture goes in front of them, a small panther makes up the rear. We also see two dancing women and a seated one who looks on from the left. A winged creature of indefinable sex hovers above the heads of the two men with a plant in its hand. In both scenes all satyrs are decked out in panther skins. The question is whether both sides of the vase can be read as one continuous scene. Unfortunately, the side views of the krater do not provide a decisive answer either. ${ }^{80}$ In any case, the level of execution is equally high on both sides: the sudden appearance of Dionyos and the arrival of the two men must have been of equal importance to the painter.

Concerning the two men we could ask ourselves who is leading who. Beazley has designated the elder Dionyos, most likely because of his thyrsos. However, by this time, Dionysos is rarely depicted bearded. Moreover, how can we explain that it is he who is looking intently at the inviting gesture of the satyr and at the beckoning maenad? The famous series of images of Herakles bringing a bearded man resembling Dionysos up from the underworld, does not show the theme we have here, but the ephedrismos motif. ${ }^{81}$ Our motif of two individuals striding forward, arms around each other's shoulders, has, as we have seen, a long history in Dionysiac imagery. It occurs for the first time

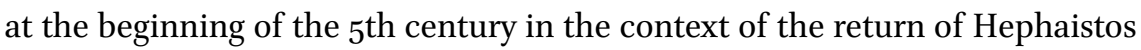
and subsequently remains in use..$^{82}$ On the basis of the tradition of the motif we can identify the elder of the two men on our vase (the one who is led) as Hephaistos, even when only a pair of tongs or a hammer could dispel all

\footnotetext{
8o Isler-Kerényi 1982, 145, figs 3-4.

81 Metzger 1951, 196 f., pl. 26, 1-3; Paul-Zinserling 1994, 24-31.

82 See above Chapter 3, note 38; London F 68 (1865.0103.14): Addenda 378 (1446.1: Pourtalès Painter); BA 218148. On the right side of the image a satyr leads Hephaistos towards Dionysos and Herakles, depicted as a pair of symposiasts.
} 
doubts. Still, if this image depicts the return of Hephaistos, it is rather surprising that it is Herakles who takes the initiative. Our discussion of, for instance, the handing over of the child Dionysos has, however, already shown the importance of taking into account unknown versions of a certain myth in view of the fluidity of the mythological tradition.

Whoever the figures in the vase may be, the meaning of the scheme is clear: euphoric reconciliation, restoration of harmony in a Dionysiac atmospherewithout the comic anecdotal element of the return of the cripple on his mule. Where are the two men going? Could it, after all, be the event on the other side of the vase? In that case the scene would unite Dionysos, Herakles and Hephaistos and, as we have just seen, this is not a unique phenomenon at this time. Despite their divine origins, all three of them were only admitted to the sphere of the gods after their vicissitudes in the world of men. ${ }^{83}$ In this way, they may have served as examples of the possible destiny of the Bacchic initiates.

\section{The Derveni Krater}

At the end of our exploration of the Dionysiac imagery of the Classical period, we must have a look at one of the most exquisite examples of Greek art: the bronze krater from Derveni (Figure 118). ${ }^{84}$ This elaborate vessel is superbly decorated both in relief and with sculpted figures. It not only served as a funerary urn for the ashes of a man and a woman, but, as the traces of wax found on the inside indicate, was especially made for this purpose. ${ }^{85}$ On the basis of other objects found in the grave, the krater may be dated between 320 and 290 BC. ${ }^{86}$ The decoration consists of a frieze of large figures in relief around the belly of the vessel, an animal frieze above the foot and another below the mouth. The neck and the upper part of the belly are decorated with branches of ivy and

83 All three not only have a divine, but also an irregular origin: Dionysos and Herakles are children of Zeus by daughters of heroes; Hephaistos was either born from the secret union of Zeus and Hera, or brought forth by Hera herself: Kerényi 1997a, 77, 115 and 117.

84 Thessaloniki B 1: LIMC III, Dionysos 755; Grassigli 1999 (including the relevant literature); Holtzmann 2010, $260 \mathrm{f}$., no. 73. The impression of gilding is caused by an exceptionally high amount of tin in the alloy, see Grassigli 1999, 109 with note 31.

85 Grassigli 1999, 109; Jaccottet 2008, 42. Tiverios 2008a seems unaware of Grassigli's thorough investigation of the preceding literature and his overall interpretation. On the other hand, Grassigli's work forms the basis of Jaccottet's argumentation.

86 Grassigli 1999, 140. Compare Holtzmann (see above note 84) according to whom the vessel could have been created at a somewhat earlier date. 


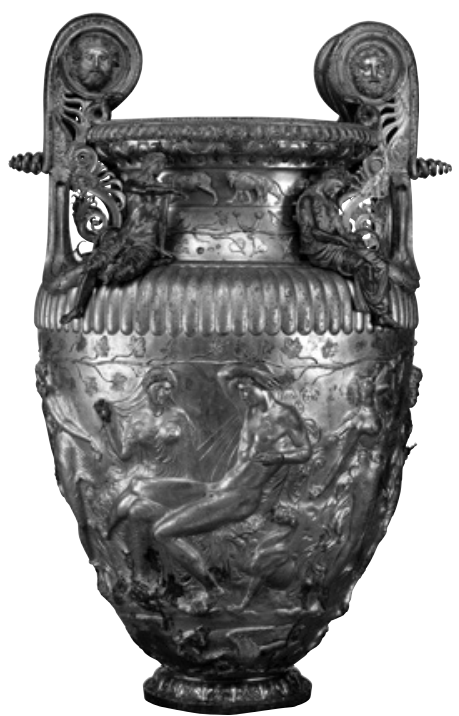

$a$

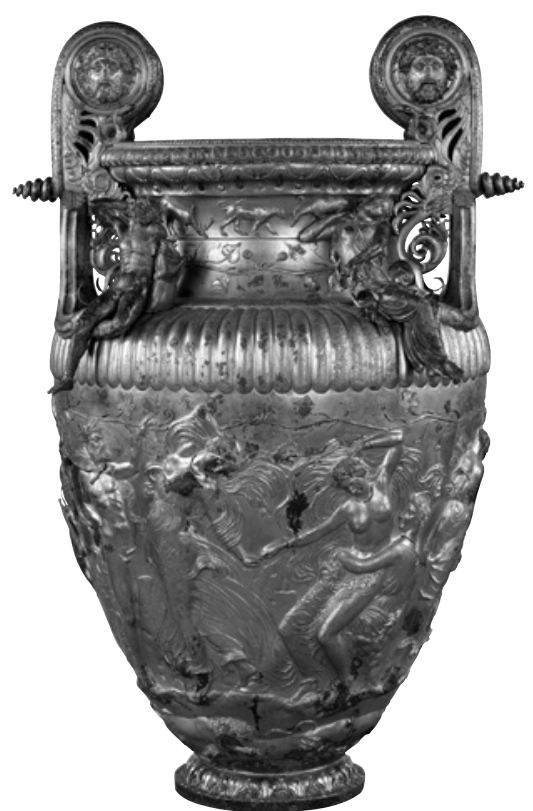

$c$

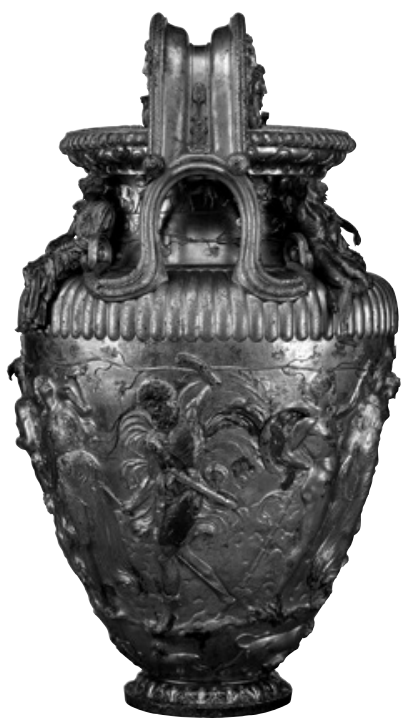

$b$

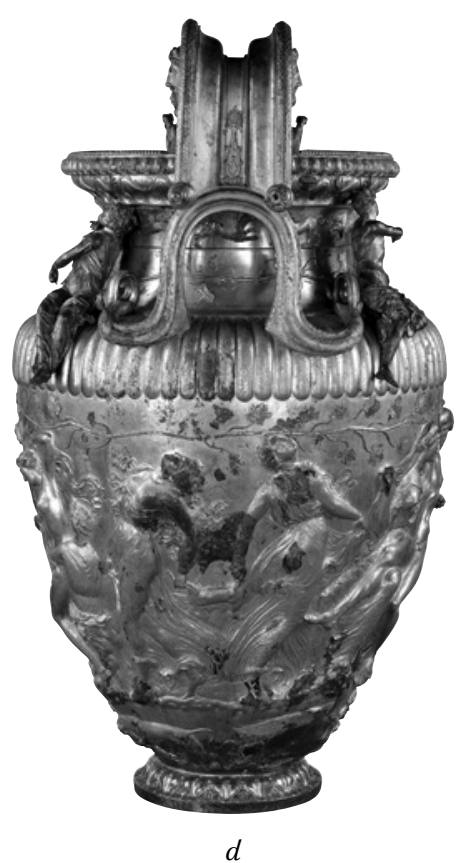

FIGURE 118 Bronze krater from Derveni, Thessaloniki, Archaeological Museum B 1 (photographs Archaeological Museum of Thessaloniki).

a. side A: Dionysos and Ariadne.

b. side view (right): Astion(?).

c. side B: bacchantes.

d. side view (left): bacchantes. 
vine. Snakes wind themselves around the medallions of the handle volutes. On both sides the medallions have bearded heads, shown full face. Four sculpted figures are sitting on the shoulders of the vase. Even after Grassigli's extensive iconographical analysis of the decoration program, questions remain. In any case, we must also consider the wreath of myrtle leaves that was put on the mouth of the vase at the time of the burial. ${ }^{87}$

The figure of the youthful Dionysos, conspicuous for its height, dominates the aspect of the main side. He is comfortably reclining on a projection in the landscape which has been covered by a cloth. His right arm is around his inclined head, and his right leg rests on the left thigh of Ariadne who sits beside him, her right hand raised in the typical gesture of the bride. We can conclude from Grassigli's argument that Dionysos is just waking up, which reminds us of the analogy between sleep and death. ${ }^{88}$ To the right of Dionysos we see a crouching panther looking up at the god. Further to the right, a maenad with a small child flung over her left shoulder is dancing furiously towards the right. ${ }^{89}$ Below the right handle, a bearded man, a sheath hanging at his side, strides animatedly towards the left. He carries a spear and wears only one boot. Among the many suggestions for the interpretation of this figure, Grassigli's well-founded contention that he should be identified as Astionthe owner of the grave, who is mentioned in an inscription incised at the mouth of the vase-makes most sense from an iconographical point of view. ${ }^{90}$ An ithyphallic satyr dancing towards the right leads us to the reverse of the krater. He looks at an ecstatically dancing maenad, whose left hand touches the right of a half-naked woman who, exhausted, seems to be falling into the lap of a companion. Below the left handle two maenads are dancing in opposite directions. Together they hold the legs of a fawn, which seems to be on the verge of undergoing his diasparagmos. ${ }^{91}$

With one exception, the lower animal frieze shows the aggressive behavior of griffins and predators attacking a fawn and a calf, whereas the upper frieze presents predators and tame animals peacefully moving along. According to

87 Compare the image of the wreath in Grassigli 1999, 111, fig. 14, with the botanical drawing in Kunze-Götte 2006, 11, fig. 1a.

88 Grassigli 1999, $128 \mathrm{f}$.

89 For other examples of the motif, see Grassigli 1999, $112 \mathrm{f}$.

9o Grassigli, 123-126; similarly Jaccottet 2008, 53. Tiverios 2008a, 204 on the other hand adheres to the identification as Lykourgos.

91 This motif can also be found on a fragmentary bronze krater in Berlin which may be dated around 400 вС: Schöne-Denkinger 2008, 49 and 52, fig. 10. 
Grassigli's view this alludes to the reconciliatory effect of Bacchic initiation. ${ }^{92}$ In his view, the bearded figure with one boot he identifies as Astion is likewise on his way towards Bacchic bliss, because he finds himself between two possible Dionysiac encounters: a peaceful one, and one characterized by the bloodthirsty acts of the dancing maenads. ${ }^{93}$ As in Euripides' Bakchai, the two approaches represent the initiates and the non-initiates. ${ }^{94}$

Of the four bearded faces in the volute medallions, only the one on the right of the main side of the vase can be identified with certainty: because of the lion skin he must be Herakles, the heros who experienced Hades. His counterpart on the left has small bull horns, like Acheloos or Dionysos Tauros. One of the two faces on the other side of the vase could perhaps be identified as Hades. However, analogous to contemporaneous Apulian ornate kraters, the position of the faces also justifies identifications such as Helios or one of the wind gods-deities who belong to the higher spheres. ${ }^{95}$ We may presume a reference to guardian deities or protective beings is intended.

The common denominator of the four seated figures attached to the shoulders of the vase is, again, the moment of awakening. On the main side, to the left, a young man, possibly Dionysos himself, turns towards a still soundly sleeping bacchante as he wakes up. On the reverse a satyr is fast asleep on a full wine sack; the bacchante to his right is just waking up. ${ }^{96}$ Because of these figures and the awakening Dionysos, sleep becomes the leading motif of the main side of the vase, which stands in sharp contrast to the violent movement of the figures of the Bacchic thiasos on the other. Like sleep, but in a different way, this movement expresses the state of ecstasy, of being outside oneself. In what way one imagined a possible life after death remains open. Reference is only made to a dissolution of boundaries, which is analogous to the one experienced in sleep and in ecstasy, and for which sleep and ecstasy are the visual metaphors. ${ }^{97}$ The message of comfort that patron and artist communicated to the beholder may be summarized as follows: just like the god himself who, overcome by sleep, will at his blissful awakening find Ariadne at his side, the Bacchic initiate may envisage a blissful awakening after death. A remarkably original element in all of this is the fact that Ariadne, the most famous sleeper

\footnotetext{
92 Grassigli 1999, $136 \mathrm{f}$.

93 Compare the pyxis from the end of the $5^{\text {th }}$ century introduced above, Chapter 8, note 70.

94 Grassigli 1999, 139. For a different interpretation see Jaccottet 2008, 56, note 40.

95 Isler-Kerényi 2008b, 240-242.

96 McNally 1985, $166 \mathrm{f}$.

97 Similar to Dionysiac sarcophagi of the Roman Imperial period: Isler-Kerényi 2012b, 75.
} 
in the history of Greek art, is awake here, whereas Dionysos, who had been the awakener since at least $400 \mathrm{BC}$, was overcome by sleep. ${ }^{98}$

The prospect of felicity in the first place concerns Astion, depicted as a bacchant. Jaccottet stresses that this depiction would have been unthinkable in the Classical polis. ${ }^{99}$ The vase imagery of the Classical period presented men in a state of Bacchic suspension in the guise of satyrs. This brings us to the following question: if the Derveni krater represents the bacchant as a dancer instead of a satyr, what then is the meaning of the satyr who, to his right, is dancing with an ecstatic maenad? The observation, made several times in the previous chapter, that after 430 BC the Dionysiac world had increasingly removed itself from the beholder of the images, may provide an explanation here: satyrs and citizens were no longer interchangeable. We can assume that the scene in the main image of the Derveni krater takes place in a paradisiacal world, which can only be imagined by the living; Astion, the monosandalos in the transitional space below the right handle, is moving towards it. ${ }^{100}$ This places the Derveni krater and its Dionysos at the end of the Classical period-at the beginning of a new era.

98 McNally 1985, 152; Apulian calyx krater, Taranto 52230: LIMC III, Ariadne 96. About this motif in monumental painting and in later times: LIMC III, Dionysos 777 and 778 .

99 Jaccottet 2008, 60.

100 After an exhaustive discussion of the motif, Grassigli 1999, 123 comes to the following conclusion: “... l'indossare un solo calzare costituisce uno degli espedienti per dichiarare alla divinità la propria adesione ai misteri.” 